Untersuchungen zur deutschen

Literaturgeschichte Band 144 

Regina Toepfer

\section{Höfische Tragik}

Motivierungsformen des Unglücks in mittelalterlichen Erzählungen

De Gruyter 


\section{ISBN 978-3-11-030697-2 \\ e-ISBN 978-3-11-030716-0 \\ ISSN 0083-4564}

Library of Congress Cataloging-in-Publication Data

A CIP catalog record for this book has been applied for at the Library of Congress.

Bibliografische Information der Deutschen Nationalbibliothek

Die Deutsche Nationalbibliothek verzeichnet diese Publikation in der Deutschen Nationalbibliografie; detaillierte bibliografische Angaben sind im Internet über http://dnb.dnb.de abrufbar.

(C) 2013 Walter de Gruyter GmbH, Berlin/Boston

Druck: Hubert \& Co. KG, Göttingen

(@) Gedruckt auf säurefreiem Papier

Printed in Germany

www.degruyter.com 